\title{
ANALISIS PERAN PENGAWASAN KANTOR IMIGRASI KOTA LHOKSEUMAWE TERHADAP KEBERADAAN ORANG ASING
}

\author{
ANALYSIS OF THE ROLE OF THE AUDIT OFFICE OF THE CITY OF \\ LHOKSEUMAWE TOWARDS SUPERVISION OF FOREIGNERS
}

\author{
Mohd. Feri Andrian ${ }^{1}$, Muhammad Nasir ${ }^{2}$, Yusrizal ${ }^{3}$ \\ (Mahasiswa Prodi Magister Ilmu Hukum, Dosen Fakultas Hukum \\ Universitas Malikussaleh, Dosen Fakultas Hukum Universitas \\ Malikussaleh) \\ Email: muhnasir@unimal.ac.id
}

\begin{abstract}
The research is based on empirical facts that there are foreigners who abuse their residence permits in Lhokseumawe City. In 2018 there were 5 cases, 1 case in 2019 and 3 cases in 2020. The study aims to analyze the monitoring mechanisms, obstacles and efforts of the Lhokseumawe TPI to supervise foreigners. This research uses empirical juridical method. The legal materials used are primary legal materials, secondary legal and tertiary legal materials. Data analysis was carried out qualitatively. The results showed that TPI supervision had not been effective due to various obstacles, namely limited human resources, wide area, lack of public understanding of the importance of supervision of foreigners. Efforts are being made, namely cross-sectoral coordination, the establishment of TIMPORA and the socialization of APOA.
\end{abstract}

\begin{abstract}
Abstrak
Penelitian didasari fakta empiris adanya orang asing yang menyalahgunakan izin tinggal di Kota Lhokseumawe. Tahun 2018 berjumlah 5 kasus, 1 kasus tahun 2019 dan 3 kasus tahun 2020. Penelitian bertujuan menganalisis mekanisme pengawasan, hambatan dan upaya TPI Lhokseumawe mengawasi orang asing. Penelitian menggunakan metode yuridis empiris. Bahan hukum yang digunakan adalah bahan hukum primer, sekunder dan bahan hukum tertier. Analisis data dilakukan secara kualitatif. Hasil penelitian menunjukan pengawasan TPI belum berjalan efektif dikarenakan berbagai hambatan, yaitu SDM terbatas, luasnya wilayah, kurangnya pemahaman masyarakat tentang pentingnya pengawasan orang asing. Upaya yang dilakukan yaitu koordinasi lintas sektor, pembentukan TIMPORA dan sosialisasi APOA.
\end{abstract}

Kata Kunci: Orang Asing, Pengawasan, TIMPORA

\section{Latar Belakang Masalah}


Orang asing yang ingin memasuki ke wilayah Indonesia diwajibkan untuk mendapatkan izin dari pejabat imigrasi. Sesuai dengan ketentuan yang telah diatur dalam pasal 48 UU Imigrasi yang mengatur bahwa setiap orang asing yang masuk ke Indonesia wajib memiliki izin tinggal. Izin tinggal yang diberikan oleh pejabat imigrasi sesuai dengan kepentingan dan kegiatan yang akan dilakukan selama berada di Indonesia dan juga sesuai dengan visa yang diberikan kepadanya. Ada beberapa izin yang dapat dikeluarkan oleh pihak imigrasi untuk memenuhi kebutuhan dari orang asing adalah sebagai berikut:

a. Izin Tinggal diplomatik;

b. Izin Tinggal dinas;

c. Izin Tinggal kunjungan;

d. Izin Tinggal terbatas; dan

e. Izin Tinggal Tetap.

Izin tersebut baru dikeluarkan oleh pejabat imigrasi setelah diperiksa seluruh dokumen perjalanan yang harus diperlihatkan kepada petugas. Mayoritas izin yang diurus oleh orang asing yang berada di Lhokseumawe adalah izin tinggal terbatas sesuai dengan keperluannya. Ada yang berstatus sebagai pekerja, santri dan lain sebagainya. Setiap izin yang dikeluarkan oleh pejabat imigrasi memiliki batasan waktu berakhirnya. Pasca berakhirnya izin tersebut maka orang asing tidak dapat berada di wilayah yurisdiksi Lhokseumawe kecuali memperpanjang Kembali.

Fakta empiris menunjukkan bahwa masih adanya orang asing yang tinggal di Lhokseumawe yang telah berakhir masa tinggalnya di Lhokseumawe, akan tetapi tidak mengajukan perpanjangan kepada pihak imigrasi. Begitu juga dengan izin yang dikeluarkan oleh TPI Kota Lhokseumawe yang sebenarnya dipergunakan untuk suatu pekerjaan, akan tetapi disalahgunakan oleh orang asing.

Praktik tersebut merupakan sebuah pelanggaran terhadap aturan keimigrasian dan pihak yang melakukan dapat dikenakan sanksi administratif berupa pendeportasian ke negara asalnya dan dapat pula dikenakan dengan sanksi pidana sesuai dengan ketentuan Keimigrasian yang berlaku di Indonesia. Jumlah 
orang asing yang melakukan pelenggaran terhadap UU Keimigrasian adalah sebagai berikut: ${ }^{1}$

\begin{tabular}{|c|c|}
\hline Tahun & Jumlah \\
\hline 2018 & 5 orang \\
\hline 2019 & 1 orang \\
\hline 2020 & 3 orang \\
\hline
\end{tabular}

Sumber: Data Kantor Imigrasi Kelas II TPI Kota Lhokseumawe

Berdasarkan tabel sebagaimana yang telah diuraikan di atas menunjukkan bahwa pelaksanaan pengawasan terhadap orang asing yang tinggal di Lhokseumawe belum efektif dilaksanakan oleh Keimigrasin TPI Kelas II Kota Lhokseumawe. Padahal di unit kerja TPI tersebut telah adalah Lembaga yang disebut dengan Tim Pengawasan Orang Asing sebagai unit yang dapat membantu mengawasi keberadaan orang asing serta kegiatan atau aktivitasnya di Lhokseumawe. Belum maksimalnya peran pengawasan ini menjadi suatu hal yang menarik untuk ditelusuri, dikaji dan dianalisis secara komprehensif melalui kajian ini. Mengingat selama ini sudah ada TPI dan juga telah dibentuk unit Tim Pengawas Orang Asing, namun dalam kenyataan empiris masih ditemukan adanya praktikpraktik pelanggaran terhadap ketentuan keimigrasian. Penelitian bertujuan untuk menganalisis mekanisme pengawasan keimigrasian terhadap keberadaan orang asing pada Kantor Imigrasi Kelas II TPI Lhokseumawe, hambatan yang dihadapi pejabat Imigrasi pada Kantor Imigrasi Kelas II TPI Lhokseumawe dalam menangani keberadaan orang asing dan upaya yang dilakukan oleh Imigrasi Kelas II TPI Lhokseumawe berkaitan dengan orang asing.

\section{Metode Penelitian}

Peneliti menggunakan metode penelitian yuridis empiris untuk menganalisis permasalahan penelitian dalam kajian ini. Data primer diperoleh melalui wawancara secara mendalam (dept interview) dengan kepala Kantor

\footnotetext{
${ }^{1}$ Data Kantor Imigrasi Kelas II TPI Kota Lhokseumawe
} 
Imigrasi Kelas II TPI Kota Lhokseumawe, 3 Orang Kepala Seksi Inteligent dan 1 orang staf kantor imigrasi. Bahan hukum primer terdiri dari, Undang-Undang Nomor 6 Tahun 2011 tentang Keimigrasian, Peraturan Pemerintah Nomor 31 Tahun 2013 tentang Peraturan Pelaksanaan Undang-Undang Nomor 6 Tahun 2011 tentang Keimigrasian. Bahan hukum sekunder diperoleh dengan cara melakukan studi dokumentasi terhadapa bahan hukum literatur perpustakaan yang membahas terkait topik pengawasan imigrasi.

\section{Hasil Penelitian dan Pembahasan}

\section{a. Mekanisme Pengawasan Keimigrasian Terhadap Keberadaan Orang Asing Pada Kantor Imigrasi Kelas II TPI Lhokseumawe}

Pengawasan di imigrasi merupakan salah satu Tindakan yang wajib dan terus menerus dilakukan oleh petugas. Hal ini bertujuan untuk memastikan kesesuaian visa yang telah diberikan dengan pelaksanaannya di lapangan. Bila adanya kemungkinan tidak dilaksanakan pengawasan secara terus menerus dan berkelanjutan maka dikhawatirkan akan terjadinya penyimpangan-penyimpangan yang menimbulkan dampak tidak baik bagi bangsa dan negara ini serta disalahgunakan kepentingannya. Menurut Fauzi.,S.H yang merupakan Kepala Kantor Imigrasi Lhokseumawe, pengawasan memiliki peranan yang sangat penting dan memang perlu untuk dilakukan oleh petugas imigrasi. Perlunya pengawasan ini tidak terlepas dari beberapa alasan sebagai berikut ${ }^{2}$ :

Pertama, untuk mengumpulkan data dan informasi terkait kebenaran dan kecocokan orang asing dengan visa yang telah diberikan kepadanya. Kadangkalanya visa yang diberikan untuk berlibur akan tetapi dalam kenyataannya justru sebaliknya yaitu visa tersebut dipergunakan untuk keperluan bekerja. Bilamana ditemukan adanya ketidaksesuaian antara visa dengan kenyataan yang sesungguhnya, pihak imigrasi akan mengambil sikap dan mendeportasikan ke negara asalnya. Kedua, untuk memberikan rasa kenyamanan kepada negara dari praktik-praktik yang dapat membahayakan dan merusak tatatan kehidupan negara Indonesia dari perilaku orang asing. ${ }^{3}$ Hal ini menyangkut dengan keselamatan

\footnotetext{
${ }^{2}$ Fauzi, Kepala Kantor Imigrasi Kota Lhokseumawe, Wawancara, 21 Mei 2021.

${ }^{3}$ Fauzi, Kepala Kantor Imigrasi Kota Lhokseumawe, Wawancara, 21 Mei 2021.
} 
bangsa juga yang harus dijaga dan diawasi secara menerus dan berkelanjutan. Menurut Okky Chahyo Nugroho keamanan dalam suatu negara dapat dikatakan aman bila kehidupan masyarakat tertib dan aman serta adanya penegakan hukum yang berorientasi pada terselenggaranya perlindungan hukum bagi masyarakat. ${ }^{4}$ Menurut Reza Syahputra, pengawasan terhadap warga negara asing perlu ditingkatkan hal ini dikarenakan seiring meningkatnya kejahatan internasional, seperti kejahatan di bidang narkotika, penyelundupan manusia dan perdagangan manusia yang dilakukan oleh orang-orang yang tidak bertanggungjawab. ${ }^{5}$

Menurut Ramli Lahay, Kasi Intelijen dan Penindakan Keimigrasian, tidak dapat dipungkiri adanya visi dan misi yang dibawakan oleh orang asing yang dapat mengancam keselamatan bangsa. Pihak inteligen akan mengawasi serta memberikan informasi kepada pihak yang berwajib untuk diberikan penindakan dan penegakan hukum dengan menjatuhkan sanksi bagi pelakunya. Baik berupa sanksi administratif dengan cara melakukan deportasi dan dikembalikan ke negara asalnya. ${ }^{6}$ Ketiga, memberikan kesejahteraan masyarakat, hal ini dikarenakan dengan adanya pengawasan bisa dipastikan kinerja orang asing di lapangan, apakah melaksanakan sesuai dengan izin yang telah diberikan atau tidak. Sehingga jikalau tidak sesuai maka posisi kerjanya dapat memberikan dampak positif bagi masyarakat untuk bekerja sehingga berdampak pada masukan dan pendapatan bagi masyarakat Indonesia dan Lhokseumawe pada khususnya. ${ }^{7}$

Sebagai konsekuensi dari pentingnya pengawasan sebagaimana yang telah penulis sebutkan di atas, maka pihak Imigrasi Lhokseumawe melakukan pengawasan bagi warga negara asing. Pengawasan ini sebagai konkretisasi kewenangannya dalam melaksanakan tugas di bidang pengawasan. Ada tiga tahapan pengawasan yang dilakukan oleh petugas imigrasi Lhokseumawe, yaitu sebagai berikut:

\footnotetext{
${ }^{4}$ Okky Chahyo Nugroho, "Penegakan Hukum Terhadap Orang Asing di Kantor Imigrasi Kelas I Denpasar Dan Kelas I Khusus Bandara I Gusti Ngurah RAI”, Jurnal Penelitian Hukum De Jure, Volume 17, Nomor 2, Juni $2017: 231$ - 247

${ }^{5}$ Reza Syahputra, "Pelaksanaan Administrasi Pengawasan Orang Asing”, Humanis Jurnal Ilmu Administrasi Negara, vol. 5, No. 1, 2019, hlm. 2019

${ }^{6}$ Ramli Lahay, Kasi Inteligen Imigrasi Lhokseumawe, Wawancara, 14 Mei 2021.

${ }^{7}$ Rahmat Hendriko, Petugas Imigrasi Kota Lhokseumawe, Wawancara, 19 Mei 2021.
} 
b. Pengawasan Administratif di Kantor Imigrasi

Sebelum orang asing beraktifitas di Lhokseumawe, Langkah utama yang harus dilakukan adalah harus mendapatkan izin dari imigrasi Lhokseumawe baik izin tinggal terbatas maupun izin menetap. Pemeriksaan kelengkapan administrasi ini dilakukan dengan tujuan agar dapat memastikan kelengkapan administrasi yang harus dipersiapkan oleh orang asing untuk tinggal di Lhokseumawe. ${ }^{8}$

Biasanya dokumen yang pertama kali diminta adalah mengecek dan memverifikasi kelengkapan seluruh dokumen atau berkas pemohon yang memohon izin tinggal dalam wilayah hukum Lhokseumawe. Bila orang asing tersebut berstatus sebagai pekerja, dokumen yang akan diverifikasi oleh imigrasi adalah IMTA (Izin Mempekerjakan Tenaga Asing) dan RPTKA (Rencana Penggunaan Tenaga Kerja Asing). Kedua izin ini dikeluarkan oleh Kementerian Tenaga Kerja sebagai bukti kejelasan tempat yang akan mempekerjakan tenaga kerja asing. Kegiatan pengawasan di Kantor Imigrasi Kelas II Lhokseumawe biasa disebut dengan Pulbaket (pengumpulan bahan keterangan) agar mendapatkan kejelasan dari orang asing tersebut. Setelah berkas sudah selesai diperiksa barulah seksi pengawasan dapat turun ke lapangan dengan seizin Kepala Kantor. Pengawasan dilakukan secara rutin dengan tujuan melihat keberadaan orang asing berada.

Pengawasan administrasi lebih maksimal dilakukan dibandingkan dengan pengawasan pengawasan di lapangan. Hal ini dikarenakan pengawasan di TPI hanya memeriksa seluruh dokumen perjalanan yang dimiliki oleh orang asing. Ketidaklengkapan dokumen yang dipersyaratkan dapat menyebabkan orang asing tersebut tidak dibenarkan memasuki ke wilayah negara Indonesia. Sebaliknya, bilamana seluruh perlengkapan syarat dipenuhi maka orang asing tersebut barulah dibenarkan memasuki ke wilayah Indonesia. Berbeda halnya dengan pemeriksaan di lapangan di mana orang asing setelah diberikan izin tinggal dengan serta merta dapat berkunjung ke daerah-daerah yang disukainya. Wilayah yang dapat dikunjungi juga sangat luas sehingga luput dari pengawasan orang asing yang mengawasinya. Pengawasan di TPI hanya mengawasi pada satu titik saja yakni di

\footnotetext{
${ }^{8}$ Hanna Pradipta Staf imigrasi, Wawancara, 19 Mei 2021.
} 
lokasi pemeriksaan, berbeda dengan pemeriksaan di lapangan yang cenderung puluhan titik untuk diawasinya.

\section{c. Pengawasan Lapangan}

Pengawasan lapangan merupakan pengawasan secara langsung yang dilakukan oleh petugas ke lokasi di mana orang asing berada. Pengawasan lapangan ini memiliki peran yang cukup signifikan bagi pihak imigrasi dalam upaya mendeteksi keberadaan orang asing serta mengidentifikasi kesesuaian antara visa dengan orang asing tersebut. Pengawasan lapangan dilakukan dengan membawa surat tugas sebagai dasar bagi petugas untuk melaksanakan tugasnya agar yang dilakukan sesuai dengan perintah yang dibenarkan oleh peraturan perundangundangan.

Ada beberapa hal yang dicek oleh pihak imigrasi terkait keberadaan orang asing di Lhokseumawe, yaitu:

Pertama, keberadaan Orang Asing; dalam hal ini pihak imigrasi ingin mendeteksi keberadaan orang asing tersebut berada di mana, apakah telah sesuai dengan izin yang diberikan atau tidak. Kedua, kegiatan Orang Asing; hal ini menjadi penting untuk dilakukan oleh petugas mengingat kadangkalanya kegiatan yang dilakukan oleh orang asing tersebut tidak bersesuaian dengan izin yang telah diberikan oleh pihak imigrasi. Untuk memastikan kebenaran sesuai atau tidaknya kegiatan tersebut maka pengawasan lapangan yang dilakukan oleh pihak imigrasi sangat penting agar dapat memaksimalkan pengawasan yang diberikan. ${ }^{9}$ Ketiga, aspek ketiga yang perlu mendapatkan perhatian dari pihak imigrasi terhadap orang asing adalah ada atau tidaknya kelengkapan dokumen perjalanan atau Izin Tinggal yang dimilikinya. ${ }^{10} \mathrm{Hal}$ ini juga untuk memastikan keabsahan tinggalnya seorang warga negara asing di Indonesia khususnya di Lhokseumawe. Bila ternyata ditemukan adanya ketidaksesuaian dokumen dengan kegiatan yang dilakukan oleh orang asing, maka akan dilakukan tindakan hukum.

\footnotetext{
9 Kharisma Subhan Inteligen Imigras Kota Lhokseumawe, Wawancara, 15 Mei 2021.

${ }^{10}$ Hanna Pradipta Staf imigrasi Kota Lhokseumawe, Wawancara, 19 Mei 2021.
} 
Menurut Fauzi, Kepala Imigrasi, mekanisme yang dilakukan selama ini dalam hal adanya pelanggaran imigrasi yang dilakukan oleh orang asing didasarkan oleh karena adanya informasi atau pengaduan yang disampaikan oleh masyarakat terkait keberadaan orang asing. ${ }^{11}$ Atas dasar laporan tersebut petugas imigrasi melakukan pengecekan langsung kebenaran informasi tersebut ke lapangan, baik di tempat orang asing itu kerja maupun di tempat lainnya sesuai dengan laporan yang diterima dari masyarakat. Pengecekan langsung ini dengan melibatkan instansi dari pemerintah daerah yaitu Kesbangpol dan Kepolisian.

Pengawasan yang dilakukan oeh Timpora dengan cara menukar informasi yang berkaitan dengan keberadaan dan kegiatan yang dilakukan oleh orang asing dengan melakukan operasi gabungan bersama dengan badan atau instansi pemerintahan terkait seperti Kepolisian Daerah, Pemerintah Daerah, Badan Intelijen Negara dan Kejaksaan Negeri Lhokseumawe.

Untuk memaksimalkan pengawasan terhadap keberadaan orang asing di Lhokseumawe, maka ada sebuah wadah yang terdiri dari lintas sektor yang terdiri dari TNI, Polri, Kejaksaan, BIN, BAIS dan Kesbangpol atau yang dikenal dengan Tim Pengawas Orang Asing (TIMPORA) untuk melakukan pengawasan secara rutin. Pengawasan rutin ini berkontribusi positif serta memberikan dampak yang baik dalam upaya mencegah terjadinya praktik penyalahgunaan visa oleh orang asing di Lhokseumawe. ${ }^{12}$ Menurut Rahmat Hendriko, kehadiran TIMPORA sebagai wadah resmi yang dibentuk oleh pemerintah bisa mengurangi praktik pelanggaran di bidang imigrasi. Operasi rutin yang dilakukan secara berkelanjutan dapat memberikan dampak bagi orang asing untuk menggunakan visa dan izin tinggal sebaik mungkin serta menghindari dari penyelewengan. ${ }^{13}$ TIMPORA sebagaimana yang diatur dalam pasal 200 PP Nomor 31 tahun 2013 tentang Peraturan Pelaksana Undang-Undang Nomor 6 tahun 2011 tentang Keimigrasian, bertugas untuk memberikan saran dan masukan terkait informasi yang berkaitan dengan pengawasan dan temuan-temuan yang diperoleh di lapangan kepada instansi atau

\footnotetext{
${ }^{11}$ Fauzi, Kepala Kantor Imigrasi Kota Lhokseumawe, Wawancara, 21 Mei 2021.

${ }^{12}$ Lasma Fakhrurrazi Inteligen Kota Lhokseumawe. Wawancara, 15 Mei 2021.

${ }^{13}$ Rahmat Hendriko Seksi inteligen Imigrasi Lhokseumawe, Wawancara, 15 Mei 2021
} 
Lembaga terkait guna dilakukan Tindakan secara hati-hati dan bertanggungjawab dalam penanganan orang asing yang berada di Indonesia.

Berdasarkan data konkrit yang diperoleh di lapangan menunjukkan bahwa ada dua pelanggaran yang seringkali dilakukan oleh orang asing di wilayah yurisdiksi imigrasi lhokseumawe, yaitu waktu izin berakhir dan penyalahgunaan izin tinggal:

1) Waktu Izin Tinggal Berakhir

Sebagaimana yang dipahami bersama bahwa sesuai dengan Pasal 48 ayat (1) Undang-Undang Imigrasi mengharuskan orang asing untuk memiliki izin tinggal di Indonesia. Izin tersebut wajib diperoleh agar memiliki legal standing bagi dirinya Ketika dipermasalahkan oleh pihak lain. Waktu izin berakhir merupakan berakhirnya batas waktu yang diberikan oleh pihak imigrasi kepada orang asing. Izin tinggal adalah izin yang diberikan kepada orang asing yang memasuki wilayah yurisdiksi Indonesia melalui Pejabat Imigrasi. ${ }^{14}$ Berakhirnya batas waktu tersebut mengharuskan orang asing untuk melaporkan kembali ke pihak imigrasi agar dapat diperpanjang kembali. Menurut Fauzi, Untuk orang asing yang datang atau tinggal di wilayah kerja Kantor Imigrasi Lhokseumawe diberikan waktu tinggal sesuai izin tinggal yang mereka punya. Untuk izin tinggal kunjungan mereka bisa tinggal selama 30 dan 60 hari serta bisa diperpanjang selama 30 hari sebanyak 4 kali. Izin tinggal terbatas Sesuai dengan izin tinggal orang asing tersebut ada yang 6 bulan, 1 tahun dan 2 tahun. Izin tinggal tetap berlaku selama 5 tahun. ${ }^{15}$

Idealnya orang asing memiliki kesadaran dari dalam diri sendiri untuk memperpanjang izin tinggalnya kepada Kantor Imigrasi. Hal ini bertujuan memberikan keabsahan bagi dirinya untuk tinggal di wilayah yurisdiksi Indonesia. Soerjono Soekanto menyatakan bahwa kesadaran hukum merupakan nilai yang ada dalam diri manusia terkait dengan aturan yang mengatur tentang persoalan serta mengkehendaki ketertiban dalam masyarakat. ${ }^{16}$

\footnotetext{
${ }^{14}$ Timbul Aman Simongkir, "Pengawasan Keimigrasian Terhadap Orang Asing Olekantor Imigrasi Kelas Ii Dumai Menurut Undang-Undang Nomor 6 Tahun 2011 tentang Keimigrasian”, JOM Fakultas Hukum, Vol. III Nomor 1, Februari 2016, hlm. 9.

${ }^{15}$ Hanna Pradipta Staf imigrasi Kota Lhokseumawe, Wawancara, 19 Mei 2021.

16 Soerjono Soekanto \& Mustofa Abdullah, 1980, Sosiologi Hukum dan Masyarakat, Rajawali, Jakarta, hlm. 96.
} 
Adanya fenomena warga asing yang tidak memperpanjang izin ke kantor imigrasi menunjukkan bahwa pengawasan orang asing sebagaimana yang diamanatkan dalam Undang-Undang Nomor 6 Tahun 2011 tidak berlaku secara efektif khususnya bagi warga negara asing. Menurut Soerjono Soekanto, suatu aturan hukum dapat dikatakan berlaku secara efektif dikarenakan 5 faktor yaitu ${ }^{17}$ : pertama, faktor hukum itu sendiri, pada hakikatnya hukum itu mengandung aspek keadilan, kemanfaatan dan aspek kepastian hukum di dalamnya. Ketiga aspek ini seyognya menjadi acuan dalam penerapannya di dalam peradilan. Pertentangan terkadang justeru terjadi dan saling bertentangan antara yang satu dengan lainnya. Seyogyanya prioritas dalam penegakan hukum mengedepankan aspek keadilan sehingga kehadiran hukum itu bisa dirasakan manfaatnya oleh masyarakat.

Kedua, penegak hukum, penegak hukum memiliki relevansinya dengan penegakan hukum. Hukum tidak dapat ditegakkan tanpa adanya penegak hukum, begitu pula sebaliknya tanpa adanya penegak hukum tidak akan berfungsi bilamana hukum tidak tersedia. Penegak hukum memiliki peran yang sangat penting dalam hal penegakan Undang-Undang Keimigrasian supaya ketentuan tersebut bisa dirasakan manfaatnya oleh masyarakat luas. Dalam hal penegakan Undang-Undang Keimigrasian, penegak hukum di dalamnya adalah penyelidik dan penyidik PPNS yang ditugaskan untuk menyelidikan ada atau tidaknya suatu pelanggaran yang dilakukan oleh masyarakat. Bilamana ditemukan adanya bukti-bukti yang cukup mengenai adanya kesalahan dari pelaku yang telah melanggar batasan-batasan yang diatur dalam UU Keimigrasian maka dapat dikenakan sanksi sebagai bentuk hukuman atas perbuatan yang dilakukannya. Baik pelanggaran terhadap kelewatan batas waktu tinggal maupun penyalahgunaan izin tinggal yang dilakukan oleh orang asing harus ditegakkan serta dijatuhkan sanksi kepadanya.

Menurut Fauzi, sanksi yang dijatuhkan kepada pelaku pelanggaran terhadap Undang-Undang Imigrasi tidak pernah dijatuhkan dengan hukuman fisik berupa penjara, akan tetapi hukuman yang dilakukan oleh pihak imigrasi bagi pelanggarnya adalah sanksi administratif dalam bentuk deportasi dari wilayah

${ }^{17}$ Soerjono Soekanto, 2007, Pokok-pokok Sosiologi Hukum, PT Raja Grafindo Persada, Jakarta, hlm. 110. 
republik Indonesia. ${ }^{18}$ Penjatuhan hukuman administratif ini tidak menimbulkan efek jera dan tidak menjadi pelajaran bagi orang lain untuk tidak melakukan pelanggaran yang sama di masa yang akan datang. Akibatnya adalah sanksi tersebut tidak berlaku secara efektif untuk menghilangkan praktik pelanggaran izin tinggal dan kelewatan batas waktu tinggal yang digunakan oleh orang asing di Lhokseumawe.

Padahal secara de jure, ketentuan dalam UU Keimigrasian memberikan kewenangan kepada pejabat imigrasi untuk menjatuhkan hukuman fisik dan denda bagi pihak orang yang telah melakukan pelanggaran terhadap izin tinggal dan batasan waktu tinggal. Berkaitan dengan sanksi pidana fisik ini ditegaskan dalam Pasal 122 huruf a dan b UU Keimigrasian yang mengatur bahwa orang asing menyalahgunakan izin atau melakukan kegiatan yang tidak sesuai dengan izin imigrasi dan menyuruh melakukan orang asing tersebut melakukan kegiatan yang tidak sesuai dengan dapat dijatuhkan pidana penjara paling lama 5 tahun dan denda Rp 500.000.000;

Ketentuan di atas memberikan petunjukan bahwa ada dua bentuk hukuman yang dapat dijatuhkan kepada pelaku pelanggaran izin tinggal dan batas waktu yaitu hukum penjara paling lama 5 tahun atau denda paling banyak Rp 500.000.000; Akan tetapi selama ini tidak pernah dijatuhkan kepada pelaku dengan pisik padahal secara dampak psikologis baik kepada pelaku maupun orang lainnya lebih efektif hukuman fisik dibandingkan dengan hukuman administratif dengan cara deportasi dan dikembalikan ke negara asalnya.

Pihak kantor imigrasi Kelas II Kota Lhokseumawe sudah dapat melakukan evaluasi terhadap pilihan sanksi yang dapat dijatuhkan kepada pelakunya. Orientasi sanksi dengan mengedepankan efek jera sudah dipikirkan dengan cara melakukan evaluasi secara komprehensif penegakan hukuman bagi pelaku pelanggaran izin tinggal. Bila hal ini kurang mendapatkan perhatian bisa dipastikan akan semakin meningkatkan lagi jumlah pelanggaran di bidang Keimigrasian. Fungsi yang sangat penting dari hukum pidan aini adalah dapat memberikan dampak atau efek jera

${ }^{18}$ Fauzi, Kepala Kantor Imigrasi Kota Lhokseumawe, Wawancara, 21 Mei 2021. 
dengan cara menjatuhkan hukuman bagi yang melakukannya. Menurut Putu Sekar Wangi, hukum pidana sebagai ultimum remedium bisa digunakan untuk menanggulangi kejahatan. ${ }^{19}$ Menurut Sudarto sebagaimana dikutip oleh Muladi, bahwa penderitaan yang diberikan kepada pelaku adalah sebagai sesuatu kesengajaan karena telah melakukan sebuah kelahan di mana kesalahan tersebut telah digarisbawahi oleh ketentuan supaya tidak dilakukan. Hingga saat ini, Imigrasi tidak pernah menjatuhkan dengan sanksi pidana yang berdampak pada efek jera agar tidak mengulangi kembali dan menjadi efek yang menakutkan bagi orang lain. ${ }^{20}$ Hal yang sama juga diungkapkan oleh Andi Istiqlal Assaad yang menyatakan bahwa salah satu ditaati suatu produk yang dibentuk oleh pemerintah adalah dengan penjatuhan sanksi bagi pelakunya. ${ }^{21}$ Pemberian sanki terhadap pelaku ini menjadi salah satu tujuan dari hukum pidana yaitu memberikan penjeraan (deterrent), hal ini ditujukan untuk pelaku sendiri dan tentunya bisa berdampak bagi calon yang memiliki potensi sebagai pelaku. ${ }^{22}$

Banyak alasan konkrit yang menunjukkan sehingga pihak keimigrasian lebih memilih hukuman sanksi administratif dibandingkan dengan sanksi penjara. Menurut Fauzi, selama ini sering dijatuhkan hukuman administrif demi mencapai efisiensi atau kecepatan proses penyelesaian. ${ }^{23}$ Orang asing setelah menjalani hukuman pendeportasian telah selesai proses penyelesaian dan tidak menunggu lama dari proses penyelidikan, penyidikan, penuntutan sampai kepada pemeriksaan di tingkat peradilan. Untuk melalui proses dan tahapan tersebut membutuhkan waktu yang lama sampai dengan penjatuhan hukuman. Langkah praktis yang ditempuh adalah dengan melakukan pendeportasian dalam hal orang asing memenuhi unsur-unsur kesalahan yang telah dilakukannya.

\footnotetext{
${ }^{19}$ Putu Sekarwangi Saraswati, “Fungsi Pidana Dalam Menanggulangi Kejahatan”, Jurnal Advokasi Vol. 5 No. .2 September 2015, hlm. 140.

${ }^{20}$ Muladi dan Barda Nawawi Arief, 1984, Teori-Teori dan Kebijakan Pidana, Bandung: Alumni, Bandung, hlm. 2.

${ }^{21}$ Andi Istiqlal Assad, Hakikat Sanksi Dalam Perspektif Hukum Pidana Indonesia Dan Hukum Pidana Islam (Studi Tentang Pidana Mati), Vol. 19 No. 2 November 2017, hlm. 50.

${ }^{22}$ A. Hamzah. 2008, Asas-Asas Hukum Pidana. Ed. Revisi, Rineke Cipta, Bandung, hlm. 28

${ }^{23}$ Fauzi, Kepala Kantor Imigrasi Kota Lhokseumawe, wawancara, 21 Mei 2021.
} 
Alasan kedua yang menjadi dasar pemilihan sanksi administratif ini adalah dikarenakan penjatuhan hukuman penjara kepada pelaku dapat membebankan biaya negara untuk memberikan biaya makan selama menjalani hukuman dalam penjara. Selama orang asing ditahan dalam penjara menjadi kewajiban dan tanggungjawab negara untuk memberikan makanan kepada dirinya sampai selesai menjalani hukuman penjara. Hal inilah yang menjadi pertimbangan dari pihak imigrasi sehingga memberikan hukuman administrasi menjadi pilihan utama dalam menangani kasus penyalahgunaan izin oleh orang asing.

Pemilihan sanksi administrasi memang sudah yang tidak bertentangan dengan ketentuan peraturan perundang-undangan, akan tetapi yang perlu menjadi focus perhatiannya adalah bagaimana dampak yang ditimbulkan setelah hukuman itu dijatuhkan. Jikalau selama ini hukuman administratif belum mampu memberikan efektifitas dalam mengurangi praktik penyalahgunaan izin tinggal bagi orang asing, maka pihak imigrasi sudah semestinya memikirkan solusi lain untuk mengurangi praktik penyahgunaan izin yang dilakukan oleh orang asing. Hal ini tentu untuk memberikan keamanan serta menghindari hal-hal yang tak diinginkan oleh orang asing terhadap warga negara Indonesia. Secara prinsipil memang waktu yang dihabiskan untuk mengikuti system peradilan pidana membutuhkan waktu, akan tetapi dampak yang ditimbulkan dari proses pelaksanaan system peradilan pidana tersebut menjadi lebih efektif dibandingkan penggunaan sanksi administratif terhadap penyalahgunaan izin yang dilakukan oleh orang asing.

UU tidak hanya memberikan sanksi kepada pelaku pelanggaran izin tinggal dan melebihi waktu tinggal (over stay), akan tetapi UU juga memberikan sanksi kepada orang yang menyuruh atau memberikan kesempatan kepada orang asing untuk melakukan pelanggaran tersebut. Akan tetapi sampai saat ini belum pernah dijatuhkan sanksi bagi pihak yang menyuruh. Idealnya pihak imigrasi melakukan koordinasi dan kerjasama dengan perusahaan di mana tempat orang asing bekerja serta meminta untuk selalu memantau batasan waktu izin tinggal serta meminta untuk dilaporkan menjelang berakhir guna mendapatkan perpanjangan dari pihak imigrasi. 
Ketiga, faktor Sarana atau Fasilitas pendukung yang dapat menjadi pendukungnya penegakan hukum. Lingkup dari fasilitas ini berupa bangunan fisik dan SDM yang dapat berfungsi dan memiliki relevansi dengan aspek penagakan hukum di bidang keimigrasian. Fasilitas pendukung ini juga mencakup tenaga manusia yang memiliki skill dan kemampuan yang terampil serta professional dalam menjalankan tugas dan tanggungjawabnya di bidang penegakan hukum.

Keempat, Faktor Masyarakat, keberadaan masyarat turut mempengaruhi efektifitas suatu aturan dalam kenyataan empiris. Masih ada orang asing yang melewati masa izin tinggal menunjukkan tidak sadar akan adanya ketentuan yang mengharuskan untuk memperpanjang izin kembali ketika izin yang sebelumnya habis waktu agar tidak terjadinya over stay (melewati waktu). Begitu pula kesadaran masyarakat sekekitar yang tinggal berdekatan dengan pihak asing tersebut harus memiliki kesadaran yang tinggi mengenai keberadaan orang asing tersebut dengan tujuan untuk memantau keberadaannya di wilayah tersebut telah sesuai atau tidak dengan yang diharuskan oleh aturan hukum yang mengatur perizinan bagi pihak asing. Selama ini, hal yang seperti masih kurang kepedulian dari warga sekita. Akibatnya adalah bukanlah suatu fenomena masih tetap akan selalu ditemukan orang asing di Lhokseumawe.

Kelima, Faktor kebudayaan, artinya bahwa kebudayaan yang berlaku pada suatu komunitas juga akan turut mempengaruhi suatu aturan hukum berlaku secara optimal. Bila suatu komunitas masyarakat memiliki tingkat kesadaran hukum yang tinggi serta menaatinya sebagaimana yang diharapkan akan memberikan pengaruh yang signifikan bagi penegakan hukum secara efektif bagi semua lapisan masyarakat.

2) Penyalahgunaan Izin Tinggal

Pelanggaran kedua orang asing yang menjadi pelanggaran secara terus menerus dilakukan di wilayah yurisdiksi Lhokseumawe adalah adanya penyahgunaan izin tempat tinggal. Secara konseptual, izin tinggal diberikan oleh Pejabat Imigrasi atau pejabat dinas luar negeri yang substansi pentingnya adalah memberikan persetujuan untuk tinggal bagi orang asing dalam wilayah Indonesia. Kepemilikan izin tinggal ini sangat penting dimiliki oleh orang asing agar 
keberadaannya di Indonesia dapat dianggap sah. Sah atau tidaknya seorang tinggal di Indonesia bagi orang asing adalah memiliki izin tingal yang dikeluarkan oleh Pejabat Imigrasi. Tanpa adanya izin tinggal ini menyebabkan keberadaannya di Indonesia menjadi tidak sah, oleh karenanya pejabat imigrasi memiliki kewenangan untuk melakukan deportasi bagi orang asing tersebut dari negara Indonesia.

Banyak faktor yang sering disampaikan oleh orang asing tidak melaporkan keberadaannya di Lhokseumawe, yaitu: pertama, kealpaan, artinya orang asing lupa bahwa izin tinggal yang dimilikinya telah berakhir. Dokumen tersebut jarang disentuh kembali setelah mendapatkan persetujuan untuk tinggal di wilayah Lhokseumawe. $^{24}$ Kedua, rutinitas yang terlalu padat, alasan kedua yang disampaikan oleh orang asing adalah karena padatnya aktivitas yang sering dilakukan di perusahaan. Akibatnya adalah tidak memiliki waktu untuk memperpanjang izin tinggal ke kantor imigrasi sehingga menyebabkan keabsahan izin tinggal menjadi tidak sah di Lhokseumawe.

\section{b. Hambatan Yang Dihadapi Pejabat Imigrasi Pada Kantor Imigrasi Kelas II TPI Lhokseumawe Dalam Menangani Keberadaan Orang Asing}

Faktor penghambat dalam pengawasan diantaranya adalah faktor SDM (Sumber Daya Manusia) dan kurangnya peran aktif masyarakat dalam memberikan informasi tentang keberadaan orang asing. Faktor pendukung dalam pengawasan adalah faktor internal yaitu dukungan kepala kantor dalam bentuk fasilitas dan faktor internal adalah adanya TIMPORA (Tim Pengawasan Orang Asing).

Kendala yang dihadapi oleh petugas imigrasi dalam mengawasi orang asing adalah:

1) Luas wilayah yurisdiksi yang menjadi tanggungjawab Imigrasi Lhokseumawe

Wilayah yurisdiksi yang menjadi tanggungjawab Kantor Imigrasi Kelas II TPI Lhokseumawe terdiri dari tiga lokasi yaitu Kota Lhokseumawe, Kabupaten Aceh Utara dan Kabupaten Bireuen. Luasnya wilayah ini menjadi suatu hambatan tersendiri bagi pihak imigrasi dalam menjangkau keberadaan orang asing yang

${ }^{24}$ Michael Antony Basaman WN Amerika, Overstay, Tape Bernard Kigben WN Pantai Gading Penyalahgunaan Izin Tinggal Orang asing. 
berada tiga lokasi sehingga menjadi suatu tantangan yang harus dihadapi dalam upaya penegakan hukum administrasi bagi orang asing yang menetap di tiga wilayah Kabupaten/Kota. ${ }^{25}$ Luasnya lokasi tanpa dibarengi dengan jumlah personel yang seimbang akan berakibat pada optimalnya pengawasan. Semakin luasnya wilayah dan jumlah personel kurang, maka dapat dipastikan layanan yang diberikan tidak maksimal. ${ }^{26}$ Akan tetapi bila dibarengi dengan jumlah personel yang cukup serta didukung oleh sarana dan prasarana yang memadai tentu akan berdampak positif dalam upaya pengawasan yang akan diberikan oleh pihak imigrasi dalam rangka mengawasi keberadaan orang asing di Lhokseumawe, Aceh Utara dan Bireuen.

\section{2) Terbatasnya Kemampuan Sumber Daya Manusia}

Sumber Daya Manusia (SDM) merupakan pihak yang paling penting dalam menegakkan dalam melaksanakan tugas-tugas di Imigrasi Kelas II TPI Lhokseumawe. SDM inilah yang akan memberikan layanan-layanan yang bersifat adiministratif dan layanan yang bersifat penegakan hukum. Menurut Hanna Pradipta staf Imigrasi, keterbatasan SDM yang tersedia di Kantor Imigrasi Lhokseumawe menjadi faktor yang sangat menentukan efektif atau tidaknya layanan yang diberikan kepada orang asing maupun kepada warga negara Indonesia. ${ }^{27} \mathrm{Hal}$ ini dikarenakan tugas yang dilakukan oleh pihak imigrasi terhadap orang asing bukan saja memberikan layanan administratif pada saat pertama kali masuk di wilayah yurisdiksi Lhokseumawe. Pengawasan akan terus berlanjut sampai dengan pengawasan lapangan dan penindakan bilamana terjadinya pelanggaran terhadap Hukum Keimigrasian yang ada di Indonesia. ${ }^{28}$ Kendala kurangnya SDM belum tertangani sampai hari ini di Kantor Imigrasi Lhokseumawe sehingga memerlukan dukungan dan penguatan kapasitas dari pusat untuk

\footnotetext{
${ }^{25}$ Hanna Pradipta Staf Imigrasi Kota Lhokseumawe, Wawancara, 19 Mei 2021.

${ }^{26}$ Ramli Lahay, Kasi Inteligen Imigrasi Lhokseumawe, Wawancara, 14 Mei 2021

${ }^{27}$ Hanna Pradipta Staf imigrasi Kota Lhokseumawe, Wawancara, 19 Mei 2021.

${ }^{28}$ Ramli Lahay, Kasi Inteligen Imigrasi Lhokseumawe, Wawancara, 14 Mei 2021
} 
memperhatikan eksistensi keimigrasian dalam melaksanakan tugas di bidang pemberian layanan public bagi masyarakat yang membutuhkan. ${ }^{29}$

Hingga saat ini, Kantor Imigrasi Kelas II TPI Lhokseumawe hanya memiliki 8 personel pada Seksi Inteligen dan Penindakan. Sehingga tumpang tindih tugas pokok dan fungsinya seringkali terjadi serta job desk juga dilakukan oleh orang yang sama. Begitu pula tugas staf terkadang diambil alih oleh intelligent begitu pula sebaliknya tugas intelligent diambil alih oleh staf guna menutupi kekosongan. ${ }^{30}$ Menurut Soerjon Soekanto, penegak hukum menjadi salah satu factor yang menyebabkan suatu aturan hukum dapat berjalan efektif. Ketidakcukupan SDM di Kantor Imigrasi ini menjadi alasan sehingga pengawasan secara maksimal belum dapat diberikan oleh petugas, baik itu pelayanan di bidang administrasi maupun pengawasan orang asing yang ada di lapangan. ${ }^{31}$ Ada beberapa alasan yang menyebabkan sehingga penambahan SDM di Kantor Imigrasi Lhokseumawe perlu ditambahkan, yaitu: ${ }^{32}$ pertama, bahwa SDM menjadi kunci utama dalam upaya pemberian layanan public bagi orang asing dan masyarakat yang membutuhkan. Bila ketersediaan SDM masih terbatas dapat dimungkinkan layanan yang diberikan menjadi tidak maksimal sehingga yang dirugikan adalah masyarakat itu sendiri yang tidak optimal menerima layanan yang disediakan oleh pemerintah.

Kedua, Kota Lhokseumawe dikenal dengan Petro Dolar yang dalam wilayah ini terdapat perusahaan minya dan gas yang sering memperkerjakan orang asing yang bertujuan menunjang pendapatan bagi Aceh sehingga sangat diperlukan dokumen administratif yang jelas yang dikeluarkan oleh pihak yang berwenang dalam hal ini adalah Kantor Keimigrasian Lhokseumawe yang telah diberikan kewenangan oleh peraturan perundang-undangan untuk membantu masyarakat dalam hal mendapatkan layanan administrasi baginya. ${ }^{33}$

\footnotetext{
${ }^{29}$ Hanna Pradipta Staf imigrasi Kota Lhokseumawe, Wawancara, 19 Mei 2021.

${ }^{30}$ Ramli Lahay, Kasi Inteligen Imigrasi Lhokseumawe, Wawancara, 14 Mei 2021.

31 Soerjono Soekanto \& Mustofa Abdullah, 1980, Sosiologi Hukum dan Masyarakat, Rajawali, Jakarta, hlm. 96.

${ }^{32}$ Hanna Pradipta Staf imigrasi Kota Lhokseumawe, Wawancara, 19 Mei 2021.

${ }^{33}$ Hanna Pradipta Staf imigrasi Kota Lhokseumawe, Wawancara, 19 Mei 2021.
} 
Ketiga, Kantor Imigrasi Lhokseumawe membawahi wilayah yurisdiksi Bireuen yang sebagaimana diketahui bahwa di Bireuen ada Dayah yang sangat terkenal sehingga banyak warga negara asing yang menuntut ilmu di Dayah kebanggan masyarakat Aceh tersebut. ${ }^{34}$ Banyaknya santri asing yang menuntut ilmu di Dayah tentunnya menimbulkan konsekuensi terhadap dokumen yang harus dipersiapkan sesuai dengan yang telah diatur secara tegas dan jelas oleh pemerintah Republik Indonesia melalui UU Keimigrasian dan dilaksanakan oleh Kantor Imigrasi Kelas II TPI Lhokseumawe.

\section{3) Pemahaman Masyarakat Terhadap Hukum Keimigrasian}

Masyarakat juga turut berkontribusi dalam upaya mengawasi keberadaan orang asing di Lhokseumawe. Rendahnya partisipasi masyarakat dalam mengawasi keberadaan orang asing dikarenakan kurangnya pemahaman terhadap konsep perizinan dan visa yang dikeluarkan oleh imigrasi bagi orang asing. ${ }^{35}$ Keterbatasan ini akan berdampak tidak baik sehingga masyarakat tidak dapat berkontribusi untuk mengawasi orang asing. Padahal keterlibatan masyarakat dalam upaya mengawasi keberadaan orang asing sangat penting. Sinergisitas keikutsertaan masyarakat harus dilibatkan agar permasalahan izin tinggal dan penyalahgunaan izin bagi orang asing dapat diatasi dengan sebaik-baiknya.

Pemberian pemahaman terkait isu-isu imigrasi yang berkaitan dengan izin tinggal, visa dan izin terbatas yang digunakan oleh orang yang berdomisili di Lhokseumawe kepada masyarakat sangat mendesak dilakukan. Hal ini didasari oleh beberapa alasan sehingga masyarakat harus dibekali dengan pemahaman terkait isu imigrasi atau pengarusutamaan informasi tentang perizinan dan layanan yang diberikan imigrasi kepada warga negara Indonesia dan orang asing yang menetap di wilayah Republik Indonesia, yaitu sebagai berikut:

Pertama, kedudukan masyarakat yang berada di Gampong dengan sangat mudah mendeteksi keberadaan orang asing yang melakukan aktivitas di lingkungannya. Dengan mengetahui dan memahami konsep perizinan bagi orang

\footnotetext{
${ }^{34}$ Ramli Lahay, Kasi Inteligen Imigrasi Lhokseumawe, Wawancara, 14 Mei 2021

${ }^{35}$ Ramli Lahay, Kasi Inteligen Imigrasi Lhokseumawe, Wawancara, 14 Mei 2021
} 
asing maka dapat menyampaikan secara leluasa informasi kepada pihak yang berwajib manakala adanya kesalahan dan pelanggaran yang dilakukan oleh orang asing sehingga pihak yang berwajib dapat mendatangi langsung ke lokasi untuk memberikan peringatan kepada orang asing tersebut.

Kedua, banyaknya masyarakat yang tidak mengetahui aturan tersebut sehingga menganggap keberadaan orang asing di Lhokseumawe menjadi hal biasa tanpa adanya interogasi lebih lanjut. Ketidaktahuan tersebut berakibat tidak baik dan akan memberikan kesempatan orang asing tinggal secara illegal di wilayah Lhokseumawe. Pemahaman hukum bagi masyarakat menjadi suatu kebutuhan yang mendesak disampaikan oleh pemerintah setempat supaya mengetahui batasan yang harus dilakukan dan ditinggalkan demi menyelamatkan bangsa dari pihak-pihak yang tidak bertanggungjawab.

Menurut penulis, pemahaman terkait pengaturan dan kebijakan berkaitan dengan imigrasi tidak hanya diberikan kepada instansi pemerintah semata, akan tetapi beberapa kelompok berikut ini perlu diberikan pemahaman secara komprehensif terkait dengan pengaturan keimigrasian. Kelompok-kelompok tersebut adalah sebagai berikut: pertama, kepada perguruan tinggi, perguruan tinggi besar yang ada di lhokseumawe harus mengetahui persoalan perizinan dan izin tinggal bagi warga negara asing. Hal ini dikarenakan orang asing yang di Lhokseumawe itu berasal dari beberapa negara seperti Yaman, Bangladesh, Republik Rakyat Tiongkok, Amerika Serikat, Thailand, Singapore, Swiis, Guine Bissau, Pantai Gading dan Malaysia untuk menimba ilmu pengetahuan di perguruan tinggi.

Sebagian dari warga negara asing tersebut menempuh pendidikan di Perguruan Tinggi yang ada di Lhokseumawe sehingga bila pimpinan telah mengetahui konsep pengaturan dan batas waktu yang seyogyanya orang asing melaporkan, maka pihak kampus dapat memberikan peringatan kepada orang asing tersebut untuk segera melaporkan kepada imigrasi. Langkah ini menjadi lebih efektif dan efisien sehingga dapat memberikan kemudahan bagi pihak imigrasi dalam menerima laporan dari orang asing tersebut untuk didata kembali dan 
memperpanjang izin tinggal bagi orang asing yang sedang menempuh pendidikan di Perguruan Tinggi.

Kedua, kepada Pimpinan Dayah, pimpinan dayah juga menjadi salah satu pilar penting dalam upaya memberikan pengawasan secara cepat dan efisien bagi Kantor Imigrasi Kelas II TPI Lhokseumawe. ${ }^{36}$ Hal ini dikarenakan di wilayah Bireuen yang masuk ke dalam wilayah tanggungjawab imigrasi Lhokseumawe memiliki sejumlah dayah besar untuk menimba ilmu agama bagi warga negara asing. Karenanya, pemahaman izin bagi pimpinan pesantren ini sangat penting sekali diberikan agar dapat memahami dan mendata Kembali warga asing yang mengenyam Pendidikan agama di dayah tersebut.

Keberadaan dayah yang menampung orang asing juga sebenarnya kalau dimanfaatkan akan berdampak positif bagi pihak imigrasi dalam rangka mempercepat pengawasan. Cara yang dapat dilakukan bisa dengan sosialisasi langsung ke dayah, dapat pula dilakukan dengan cara menyebarluaskan spanduk dan media campaign lainnya ke daya supaya menjadi informasi tambahan kepada pimpinan dan seluruh santri yang ada di Dayah.

Ketiga, kepada perusahaan, sebagai wilayah yang terkenal dengan petro dolar, di mana banyaknya perusahaan minyak dan gas yang memperkerjakan orang asing di perusahaannya tentu harus mengetahui tentang izin tinggal terbatas dan izin tinggal tetap serta visa bagi warga negara asing. Hal ini dikarenakan agar dapat memudahkan bagi petugas imigrasi dalam melacak keberadaan orang asing tersebut serta melakukan pengawasan baginya.

Kontribusi yang dapat dilakukan oleh perusahaan dalam mengawasi orang asing adalah dengan cara menetapkan SOP khusus bagi pekerja asing yang bekerja harus mengikuti dan mematuhi aturan yang telah ditetapkan oleh pihak imigrasi. Bila tidak dipenuhi maka tidak diboleh untuk bekerja. Hal ini sangat tepat dilakukan dan bisa mempercepat penanggulangan orang asing yang kelebihan izin tinggal dan penyalahgunaan izin tinggal di Lhokseuwawe. Tapi, hal ini masih minim sekali

\footnotetext{
${ }^{36}$ Rahmat Hendriko Seksi inteligen Imigrasi Lhokseumawe, Wawancara, 15 Mei 2021
} 
dimanfaatkan, pada secara efektif tentu sangat efektif dan efisien untuk meminimalisir pelanggaran di bidang keimigrasian.

\section{c. Upaya Imigrasi Kelas II TPI Lhokseumawe dalam Memaksimalkan Pengawasan Orang Asing}

Dalam rangka memaksimalkan peran pengawasan terhadap orang asing dari kantor Lhokseumawe sangat mendesak dilakukan agar keberadaan orang asing di Lhokseumawe benar-benar sesuai dengan prosedur dan SOP yang telah ditetapkan oleh pemerintah. Beragam upaya telah dilakukan oleh untuk memaksimalkan peran pengawasan orang asing adalah sebagai berikut:

1) Melakukan Koordinasi dengan Instansi Terkait

Koordinasi dengan lintas sector terkait menjadi salah satu yang tepat untuk memaksimalkan peran pengawan di Kantor Imigrasi Lhokseumawe. Hal ini dikarenakan berbicara tentang orang asing tidak terlepas dari berbagai sector yang terlibat, baik itu Lembaga pemerintahan maupun swasta yang harus memiliki andil terhadap pengawsan ini. Lembaga pemerintah yang terkait dengan keamanan seperti Polri dan instansi berkaitan dengan kedaulatan negara TNI dan Lembaga Kesbangpol serta perusaan yang memperkerjakan orang asing perlu adanya sinergisitas agar memudahkan pihak imigrasi dalam mendata dan mendeteksi keberadaan orang asing yang berada di Lhokseumawe.

Menurut Fauzi.,S.H salah satu langkah konkrit yang telah dibangun selama ini dalam upaya memudahkan pendataan warga negara asing adalah mensinergikan dengan berbagai pihak yang saling berkaitan. ${ }^{37} \mathrm{Hal}$ ini tentu tidak boleh dilepaskan peran dari masing-masing sektor, baik di sektor keamanan maupun pada sektor usaha. Kerjasama yang baik antar berbagai pihak yang terlibat akan menghasilkan dampak yang positif demi menjaga keutuhan.

2) Membentuk TIMPORA (Tim Pengawasan Orang Asing)

TIMPORA terdiri dari beberapa instansi di tingkat pemerintahan daerah yang diberikan mandate dan kewenangan untuk mengawasi orang asing yang terdiri

${ }^{37}$ Fauzi, Kepala Kantor Imigrasi Kota Lhokseumawe, Wawancara, 21 Mei 2021. 
dari lintas sector. TIMPORA ini menjadi senjata paling ampuh saat ini di Lhokseumawe dalam hal pendeteksian keberadaan warga negara asing. Sehingga bisa menjadi instrument untuk menjangkau keberadaan orang asing sampai ke akarakarnya.

3) Sosialisasi Aplikasi Pelaporan Orang Asing (APOA) bagi Masyarakat

Aplikasi Pelaporan Orang Asing (APOA) merupakan aplikasi yang dilaunching oleh Kementerian Hukum dan HAM pada tahun 2015 dengan tujuan memudahkan bagi pihak imigrasi untuk mendeteksi orang asing di Indonesia. Pihak perusahaan dan penginapan memiliki kewajiban untuk melaporkan setiap orang asing yang bekerja di perusahaan dan menginap di hotel. Pihak Imigrasi Lhokseumawe telah melakukan sosialisasi secara intensif kepada pihak perusahaan dan penginapan untuk melaporkan orang asing. Model pelaporan ini sangat efesien dan memberikan kemudahan bagi pihak hotel atau penginapan, perusahaan dan pihak imigrasi dalam mengawasi keberadaan orang asing.

Pihak perusahaan dan perhotelan memiliki kewajiban untuk memberikan informasi keberadaan orang asing di Lhokseumawe. Berdasarn Pasal 72 UU Keimigrasian dalam hal pihak imigrasi meminta data orang asing kepada usaha perhotelan, maka wajib diberikan. ${ }^{38}$ Karenanya, Kerjasama dengan pihak hotel dan penginapan sangat dibutuhkan agar pengawasan orang asing bisa dilaksanakan secara maksimal. Selama ini pihak penginapan sangat koperatif memberikan informasi bila pihak imigrasi memintanya. Keseriusan dan komitmen berbagai pihak memang sangat dibutuhkan demi menjaga keselamatan bangsa dan negara dari visi dan misi yang tersebunyi orang asing.

\section{Kesimpulan}

Berdasarkan pembahasan dapat disimpulkan bahwa pengawasan orang asing di wilayah yurisdiksi Lhokseumawe sangat penting dilakukan secara terus menerus dan berkelanjutan. Pengawasan yang dilakukan oleh Kantor Imigrasi Kelas II TPI Lhokseumawe melalui dua tahapan yaitu pada tahap yaitu pengawasan

${ }^{38}$ Budy Mulyawan, "Kendala Implementasi Aplikasi Pelaporan Orang Asing (APOA)", JIKH Vol. 11, No. 3 November 2017, hlm. 288. 
administratif dan pengawasan lapangan. Pengawasan yang dilakukan oleh Kantor Imigrasi Kelas II TPI Lhokseumawe belum maksimal yang ditandai dengan belum sepenuhnya orang asing mengikuti peraturan perundang-undangan khususnya berkaitan dengan kelebihan masa tinggal (over stay) dan penyalahgunaan izin tinggal. Pelanggaran yang ditangani pada tahun 2019 berjumlah 2 orang, tahun 2020 meningkat menjadi 3 orang dan pada tahun 2021 berjumlah 1 orang.

Pengawasan yang dilakukan oleh Kantor Imigrasi Kelas II Lhokseumawe masih banyak kendala, yaitu: pertama, luas wilayah yurisdiksi yang menjadi tanggungjawab Imigrasi Lhokseumawe yakni tiga Kabupaten/Kota yaitu Kota Lhokseumawe, Kabupaten Bireuen dan Aceh Utara. Kedua, terbatasnya SDM yang disediakan sehingga berbanding terbalik dengan jumlah wilayah yang harus diawasi sehingga menjadi tantangan tersendiri yang dihadapi oleh petugas di lapangan. Ketiga, rendahnya pemahaman masyarakat terhadap batasan waktu izin tinggal dan penyalahgunaan izin tinggal yang dilakukan oleh orang asing. Keempat, lemahnya pemahaman Tim Pengawasan Orang Asing (TIMPORA) terhadap konsep-konsep pengawasan orang asing. Kelima, kurangnya kepedulian masyarakat terhadap keberadaan orang asing di sekitarnya sehingga bisa mempengaruhi melebihnya waktu tinggal bagi orang asing dan ketidaksesuaian izin yang diberikan dengan pelaksanaan di lapangan yang digunakan oleh orang asing.

Upaya yang telah dilakukan adalah melakukan koordinasi dengan instansi terkait terkait pengawasan yang harus diperketat, membentuk TIMPORA (Tim Pengawasan Orang Asing) sebagai ujung tombak yang akan melakukan pengawasan secara komprehensif terkait izin tinggal dan penyalahgunaan izin tinggal bagi orang asing dan melakukan sosialisasi Aplikasi Pelaporan Orang Asing (APOA) bagi Masyarakat.

\section{DAFTAR PUSTAKA}

\section{a. Buku}

A. Hamzah. 2008, Asas-Asas Hukum Pidana. Ed. Revisi, Rineke Cipta, Jakarta.

Muladi dan Barda Nawawi Arief, 1984, Teori-Teori dan Kebijakan Pidana, Alumni, Bandung. 
Soerjono Soekanto \& Mustofa Abdullah, 1980, Sosiologi Hukum dan Masyarakat, Rajawali, Jakarta.

Soerjono Soekanto, 2007, Pokok-pokok Sosiologi Hukum, PT Raja Grafindo Persada, Jakarta.

\section{b. Jurnal}

Andi Istiqlal Assaad, "Hakikat Sanksi Dalam Perspektif Hukum Pidana Indonesia Dan Hukum Pidana Islam (Studi Tentang Pidana Mati)", Jurnal Ilmu Hukum, Vol. 19 No. 2 November 2017.

Budy Mulyawan, "Kendala Implementasi Aplikasi Pelaporan Orang Asing (APOA)", JIKH Vol. 11, No. 3 November 2017.

Okky Chahyo Nugroho, "Penegakan Hukum Terhadap Orang Asing di Kantor Imigrasi Kelas I Denpasar Dan Kelas I Khusus Bandara I Gusti Ngurah RAI", Jurnal Penelitian Hukum De Jure, Volume 17, Nomor 2, Juni 2017.

Putu Sekarwangi Saraswati, "Fungsi Pidana Dalam Menanggulangi Kejahatan, Jurnal Advokasi, Vol. 5 No. 2 September 2015.

Reza Syahputra, "Pelaksanaan Administrasi Pengawasan Orang Asing", Humanis Jurnal Ilmu Administrasi Negara, vol. 5, No. 1, 2019.

Timbul Aman Simongkir, "Pengawasan Keimigrasian Terhadap Orang Asing Olekantor Imigrasi Kelas Ii Dumai Menurut Undang-Undang Nomor 6 Tahun 2011 tentang Keimigrasian”, JOM Fakultas Hukum, Vol. III Nomor 1, Februari 2016.

\section{c. Peraturan Perundang-undangan}

Undang-Undang Nomor 6 Tahun 2011 tentang Keimigrasian.

Peraturan Pemerintah RI Nomor 31 Tahun 2013 Tentang Peraturan Pelaksanaan Undang-Undang Nomor 6 Tahun 2011 tentang Keimigrasian.

Peraturan Menteri Hukum Dan Hak Asasi Manusia Republik Indonesia Nomor 4 Tahun 2017 tentang Tata Cara Pengawasan Keimigrasian.

\section{BIODATA PENULIS}

Penulis Pertama: 


$\begin{array}{ll}\text { Nama } & : \text { Mohd. Feri Andrian } \\ \text { Tempat, Tanggal Lahir } & : \text { Sungai Pinang, 1 Februari } 1987 \\ \text { Jenis Kelamin } & : \text { Laki-Laki } \\ \text { Alamat Lengkap } & : \text { Jln. Air Bersih, Komplek Imigrasi Kuta Blang } \\ & \text { Lhokseumawe. } \\ \text { No HP } & : \text { 082185277888 } \\ \text { Email } & : \text { mohdferrya@ymail.com } \\ \text { Pekerjaan } & : \text { PNS } \\ \text { Institusi } & : \text { Kantor Imigrasi Lhokseumawe }\end{array}$

Pendidikan Forma:
a. SD N 3 Sungai Pinang 1998;
b. Madrasah Tsanawiyah 2001;
c. SMA 1 Tanjung Raja 2004;
d. Universitas Sjakhyakirti 2012. 